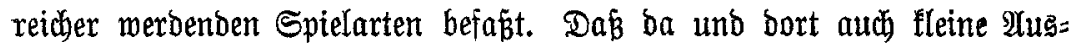
itellungen zu maden wären, ift folbitueritändlich, Denn abjolute $\mathfrak{B o l l f o n t m e n =}$ heit ijt unerreidbar.

Dingler.

\title{
IV. Mlutizent.
}

Golzartenfarte des Grokßherzogtums Baden.

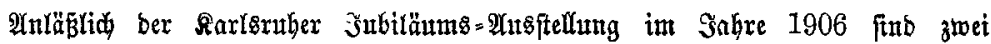

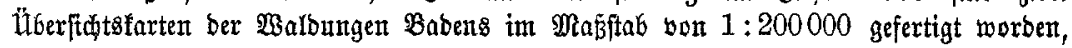

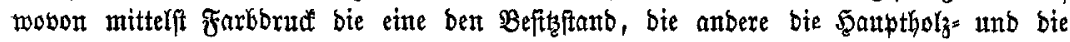
Betriefsartent nad jeşigem Stand veranjajaultidt. Bon biefen beiben Rarten bürfte bie Şolzartenfarte tweitere Ireife intereffiteren; fie ift fitr unfer Lanb bie erfte auf

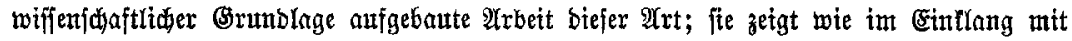
ber Mannigfaltigfeit unferes Ranbes in Beziebung auf Boben, \&àge unb Rlinta bie sont

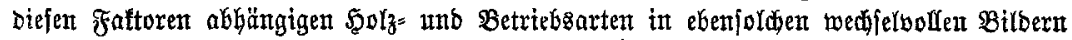

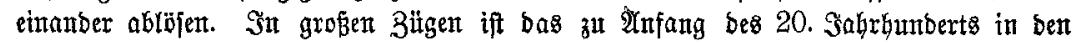

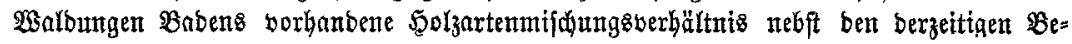
triebsarten feítgelegt.

Um bas Rartenwerf ben um bie Forftwirtidaft fich interefferenten areifen zut

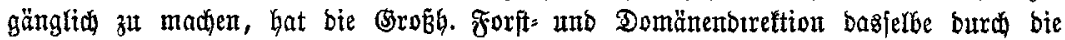

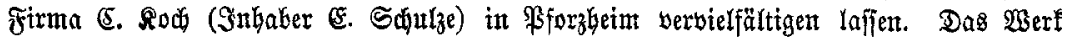
enthällt in einer Mappe 6 Blätter in Farbenbrud und 1 בitelblatt nebft 1 Seft

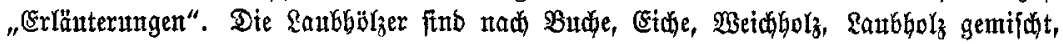

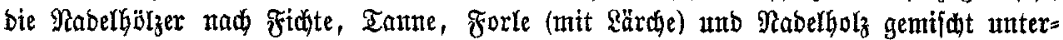

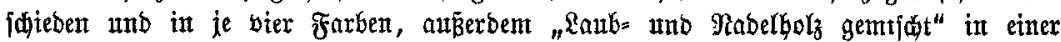
weiteren Farbe, zufammen 9 verjdiesene Farben, Dargeftellt, bie nebjt Den Betriebearten

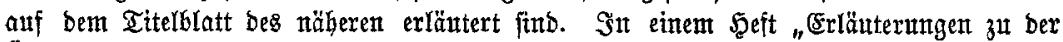

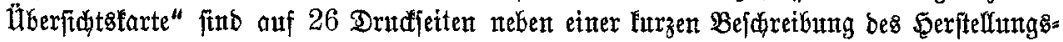

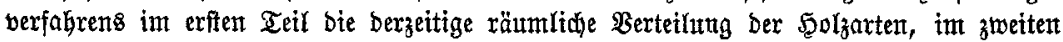

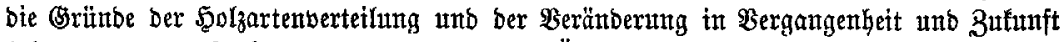

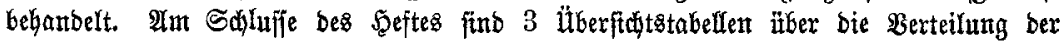

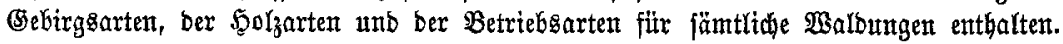

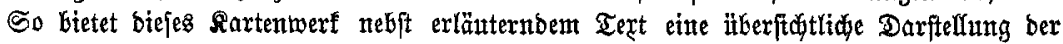

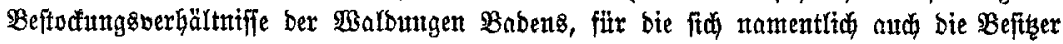

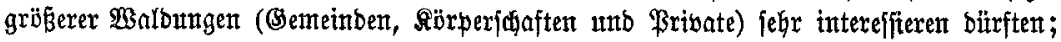

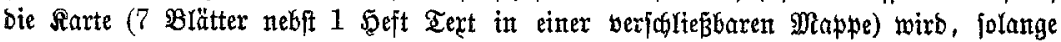

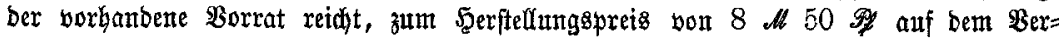

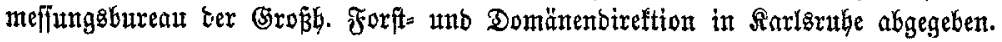

\section{Erfte internationale Jagdausftellung in wien im Jahre 1910. Uufruf.}

Die unter bem \$roteftorate Sr. Majeftät bes Raifierz Franz $\mathfrak{S o f e p h ~ I . ~ i m ~}$

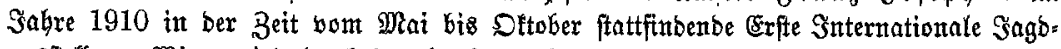
ausftellumg $\mathfrak{B i e n}$ mirb banf ber bereits gefiderten offiziellen, ber sielfnch zugejagten 